\title{
EFFICACY OF PRE-EMERGENCE HERBICIDES ON THREE ANNUAL GRASS WEEDS IN DIFFERENT SOILS
}

\author{
T.K. JAMES and A. RAHMAN \\ AgResearch, Ruakura Research Centre, Private Bag 3123, Hamilton 3240, \\ New Zealand
}

Corresponding author: trevor.james@agresearch.co.nz

\begin{abstract}
Pot experiments evaluated the efficacy of several pre-emergence herbicides on three annual grasses that are major problem weeds in most maize growing regions. Herbicides evaluated included alachlor, metolachlor, dimethenamid, two formulations of acetochlor, and proprietary mixes of acetochlor with atrazine or metribuzin. Pots were filled with soil collected from the top $10 \mathrm{~cm}$ of seven maize (Zea mays) fields with different cropping histories, and seeded with test grasses. Herbicides were applied immediately after sowing with a precision glasshouse sprayer. Additional seeds were sown at 2-weekly intervals for 8 weeks. Seedlings were counted 2 weeks after each planting. Metolachlor was most effective in controlling summer grass (Digitaria sanguinalis) and rough bristle grass (Setaria verticillata). All herbicides were less effective against the large seeded broom corn millet (Panicum miliaceum) than the other grasses. All the herbicides except metolachlor were less effective in soils with a long history of maize growing. Keywords: maize, herbicide efficacy, grass weeds, chemical control, Setaria verticillata, Digitaria sanguinalis, Panicum miliaceum.
\end{abstract}

\section{INTRODUCTION}

Weed competition is the main factor affecting maize (Zea mays) production and the critical weed-free period for maximum production has been established (James et al. 2000, 2006). Traditionally, the weed-free period has been maintained with pre-emergence herbicides (Rahman 1985), but recently the use of post-emergence herbicides has additionally been required (James et al. 2006, 2007). The increasing use of post-emergence herbicides in maize crops indicates that the phytotoxic activity of the pre-emergence herbicide no longer persists for the duration of the critical weed-free period. There are several possible reasons for this but the three most plausible are: (1) with maize often planted a month earlier than it was 30 years ago, the critical weed-free period is longer due to the crop's slower growth (based on the Plant \& Food Research maize growth model, Reid et al. 1999) and the pre-emergence herbicide fails to persist for the extended time, (2) the weed spectrum is changing towards more difficult to control weeds, especially grass weeds, and (3) pre-emergence herbicides do not persist for as long in soils with a long history of maize production, as was discovered with EPTC + antidote over 25 years ago (Rahman \& James 1983).

The work presented here investigated the efficacy of several pre-emergence herbicides on three grass weeds in soils with both short and long histories of maize production.

\section{MATERIALS AND METHODS}

The three grass weeds investigated were summer grass (Digitaria sanguinalis), rough bristle grass (Setaria verticillata) and broom corn millet (Panicum miliaceum). Fresh seeds obtained from plants grown in the glasshouse were used, with no pre-conditioning, for all the experiments. 
Soils were obtained from Waikato, Bay of Plenty and Poverty Bay regions and were paired from the same farm for short (first or second year in maize) or long (more than 10 years) histories of maize production. The Waikato soil was an Otorohanga silt loam (4.5\% organic carbon) from south of Te Awamutu; the Bay of Plenty soil was a Ohinepanea loamy sand (3.0\% organic carbon) from Matata; and the Poverty Bay soil was a Kaiti silt loam (2.5\% organic carbon) from Gisborne. A high organic matter, peat based soil with a long history of maize (Kaipaki silt loam, $21 \%$ organic carbon) from the Waikato was also included in the study. Soil from these sites was collected in bulk from the top $0-10 \mathrm{~cm}$ in autumn and stored over winter in unsealed containers at room temperature until used.

The herbicides evaluated included two formulations of acetochlor (Roustabout ${ }^{\circledR}$ and Sylon ${ }^{\circledR} 840$ ), alachlor $\left(\right.$ Corral $^{\mathrm{TM}}$ ), metolachlor (Dual ${ }^{\circledR}$ Gold), dimethenamid (Frontier ${ }^{\circledR}$ ) and acetochlor formulated with either atrazine (Calais $\left.{ }^{\circledR}\right)$ or metribuzin (Spark ${ }^{\mathrm{TM}}$ ). All herbicides were applied at highest label recommended rates.

Soil was placed in $500 \mathrm{~g}$ capacity pots (except for the Kaipaki silt loam where $1.5 \mathrm{~kg}$ pots capacity were used), seeded with ten seeds of individual species at about $5 \mathrm{~mm}$ depth and the pre-emergence herbicide applied immediately after sowing. The herbicides were applied through a $\mathrm{CO}_{2}$ powered moving belt precision sprayer fitted with a single, even spray TeeJet $8001 \mathrm{E}$ nozzle to apply 200 litres/ha at $200 \mathrm{kPa}$. After treatment the pots were lightly irrigated with a sprinkler to activate the herbicide. The plants were maintained outside with sprinkler irrigation applied similarly to all pots as required. After 2 weeks the emerged seedlings were counted (and left in the pot), and a further ten seeds were planted into the same pots. The seeds were individually pushed into the soil with a wire probe to cause minimal surface disturbance. This process was repeated every 2 weeks for up to 8 weeks after treatment. Each grass species/herbicide combination was replicated eight times except for the peat soil in the larger pots, which was replicated four times. Eight replicates of each grass species were also planted into untreated pots of each soil type on day zero to confirm seed germination. The trial data were subjected to ANOVA to separate the treatment means and main effects were obtained using Minitab ver.15.

\section{RESULTS AND DISCUSSION}

At 2 weeks after treatment the seed in the untreated pots had germinated well, with all species having $90-100 \%$ germination. In the treated pots, very few $(<3 \%)$ summer grass and rough bristle grass seeds emerged from the first two plantings (weeks 0 and 2, Table 1 ) in any of the soils. More broom corn millet seedlings emerged but still generally less than $5 \%$ of that planted. Seedling emergence from the 4-week planting was still below $15 \%$ for both summer grass and rough bristle grass. At this stage there were significantly fewer summer grass plants in the pots treated with metolachlor than in any other treatment and generally fewer rough bristle grass plants in pots treated with metolachlor or either of the two acetochlor mixtures. The emergence of broom corn millet was again greater than that of the other two grasses and was generally more consistent over all treatments, although there were significantly fewer plants in the metolachlor treatment than in the two least effective treatments (acetochlor (Sylon) and dimethenamid).

For both summer grass and rough bristle grass the largest differences between herbicide treatments occurred at the 6-week planting. Up to 6 weeks of residual weed control has previously been reported as the expected norm from pre-emergence herbicides in maize (Rahman 1985; Rahman \& James 1994). This was barely achieved in the present study, with up to $46 \%$ of the seed planted at this time emerging. Again there were fewer seedlings in the pots treated with metolachlor, but this was only significant in the case of summer grass (Table 1). About $30 \%$ of the planted seed of broom corn millet also emerged, but for this weed there was little difference between the various herbicide treatments with acetochlor + metribuzin giving the best control. By week 8 the emergence of all three grass species was greater than $50 \%$ but metolachlor was still giving significantly better control of summer grass and rough bristle grass than other herbicide treatments. 
TABLE 1: Number of grass seedlings that emerged after each seeding in pots sprayed with one of seven herbicide treatments. Values are the mean of seven soil types.

\begin{tabular}{|c|c|c|c|c|c|c|}
\hline \multirow[b]{2}{*}{ Treatment } & \multirow{2}{*}{$\begin{array}{c}\text { Rate } \\
\text { (kg ai/ha) }\end{array}$} & \multicolumn{5}{|c|}{ Weeks after treatment when seeds were sown } \\
\hline & & 0 & 2 & 4 & 6 & 8 \\
\hline & & \multicolumn{5}{|c|}{ Summer grass (seedlings/pot) $^{1}$} \\
\hline Acetochlor (Roustabout) & 2.52 & 0.1 & 0 & 1.1 & 3.1 & 6.6 \\
\hline Acetochlor (Sylon) & 2.52 & 0.1 & 0.1 & 1.4 & 4.0 & 7.4 \\
\hline Alachlor & 3.36 & 0.1 & 0.2 & 1.3 & 4.6 & 7.6 \\
\hline Metolachlor & 1.92 & 0.3 & 0.1 & 0.3 & 1.0 & 5.2 \\
\hline Dimethenamid & 1.80 & 0.1 & 0 & 0.9 & 3.9 & 7.1 \\
\hline Acetochlor+atrazine & $2.52+1.5$ & 0 & 0 & 0.9 & 4.3 & 7.4 \\
\hline Acetochlor+metribuzin & $2.1+0.53$ & 0 & 0 & 1.3 & 3.3 & 6.0 \\
\hline \multirow[t]{2}{*}{$\operatorname{LSD}(\mathrm{P}=0.05)$} & & 0.15 & 0.12 & 0.50 & 1.00 & 0.82 \\
\hline & & \multicolumn{5}{|c|}{ Rough bristle grass (seedlings/pot) ${ }^{1}$} \\
\hline Acetochlor (Roustabout) & 2.52 & 0 & 0 & 1.0 & 3.0 & 6.0 \\
\hline Acetochlor (Sylon) & 2.52 & 0 & 0 & 1.1 & 3.1 & 6.1 \\
\hline Alachlor & 3.36 & 0 & 0.1 & 1.6 & 3.6 & 6.5 \\
\hline Metolachlor & 1.92 & 0 & 0 & 0.6 & 1.8 & 5.1 \\
\hline Dimethenamid & 1.80 & 0 & 0 & 1.3 & 3.7 & 6.8 \\
\hline Acetochlor+atrazine & $2.52+1.5$ & 0 & 0 & 0.5 & 3.4 & 6.7 \\
\hline Acetochlor+metribuzin & $2.1+0.53$ & 0 & 0.1 & 0.7 & 2.5 & 5.6 \\
\hline \multirow[t]{2}{*}{$\operatorname{LSD}(\mathrm{P}=0.05)$} & & ns & 0.06 & 0.49 & 0.74 & 1.00 \\
\hline & & \multicolumn{5}{|c|}{ Broom corn millet (seedlings/pot) ${ }^{1}$} \\
\hline Acetochlor (Roustabout) & 2.52 & 0.3 & 0.6 & 1.3 & 3.0 & 7.0 \\
\hline Acetochlor (Sylon) & 2.52 & 0.3 & 0.4 & 1.5 & 2.9 & 7.9 \\
\hline Alachlor & 3.36 & 0.3 & 0.8 & 1.2 & 3.0 & 7.4 \\
\hline Metolachlor & 1.92 & 0.4 & 0.7 & 1.0 & 3.0 & 7.4 \\
\hline Dimethenamid & 1.80 & 0.3 & 0.8 & 1.6 & 3.4 & 7.9 \\
\hline Acetochlor+atrazine & $2.52+1.5$ & 0.4 & 0.5 & 1.5 & 3.5 & 9.4 \\
\hline Acetochlor+metribuzin & $2.1+0.53$ & 0.1 & 0.4 & 1.4 & 2.4 & 6.3 \\
\hline $\operatorname{LSD}(\mathrm{P}=0.05)$ & & 0.20 & 0.29 & 0.52 & 0.63 & 1.21 \\
\hline
\end{tabular}

${ }^{1}$ Average seedling numbers in untreated were: summer grass 9.4, rough bristle grass 10.0 and broom corn millet 10.0 seedlings/pot. 
Significant differences were recorded in the efficacy of various herbicides between the different soils. These differences were most noticeable with summer grass and least obvious with broom corn millet. Similar to the differences between herbicide treatments noted earlier, differences between the soils were most obvious in the emergence of seedlings from the 6-week planting. Therefore only data from this planting are presented here (Table 2).

Overall, soil organic carbon content appeared to have little influence on the activity of the various herbicides, with their activity in the high organic carbon content Kaipaki silt loam (Table 2) similar to that of the other soils with considerably lower organic carbon content. This generally contrasts with the common expectation of reduced herbicidal activity in soils with high organic carbon content (Rahman \& James 2002). However, Rahman et al. (1976) showed that the chloroacetamide herbicide alachlor was sorbed to the soil less than herbicides like atrazine and trifluralin. Furthermore, the rate of sorption was not proportional in peaty soils due to their lower bulk density.

Summer grass is a common weed of maize in all three regions where soils were collected. Of the three species, it also has the smallest seed with a thousand seed weight of $0.61 \mathrm{~g}$ (cf. rough bristle grass $1.35 \mathrm{~g}$ and broom corn millet $4.35 \mathrm{~g}$ ). The small size of summer grass seed appears to have made it more sensitive to the biologically active concentrations of herbicide in soil, as initially the control of summer grass was better than the other two grasses. Thus, the differences between the soils were generally more noticeable with summer grass than with the other two grass species (Table 2). However, after the 6- and 8-week plantings more summer grass emerged than the two larger seeded species and the differences between the soils were less accentuated. Control of summer grass from all the herbicides evaluated was similar in the Otorohanga, Kaiti and Kaipaki soils with metolachlor being better in every case (Table 2). In Ohinepanea, soil control of this weed was significantly poorer although again metolachlor was better than the other herbicides. The reason for the generally poor performance of the herbicides in the Ohinepanea soil is not immediately obvious but in practice the grower at this site also has a major problem controlling this particular weed species.

Rough bristle grass is more common in Poverty Bay than in either the Bay of Plenty or Waikato regions, with many growers in Poverty Bay facing problems in managing this weed. Similar to summer grass, metolachlor gave significantly better control of rough bristle grass in all soils, except the high organic content Kaipaki silt loam.

Currently broom corn millet is not present in either Waikato or Bay of Plenty but is an emerging and serious weed in Poverty Bay. Results from this study offer little help in managing this weed. Not only were significantly more broom corn millet plants able to grow within 2 weeks of herbicide application, but all herbicides evaluated were equally poor in controlling this weed. This could be due to the larger size of its seed, which enables the plant to emerge quickly and grow vigorously, and thus it is more able to overcome the damaging effects of the herbicide in the soil than the other two grasses.

Generally all herbicides, except metolachlor, exhibited reduced phytotoxicity in the soils with a long history of maize growing. It is difficult to explain these differences in terms of soil properties and the best explanation appears to be that of enhanced microbial degradation (Krutz et al. 2007). These researchers have noted a trend that soils with a long history of using particular herbicides also have the ability to break down those and related herbicides more rapidly (Krutz et al. 2008). This could also explain why the combination products evaluated in this study had reduced efficacy in the soils with a long history of maize growing, as few of these fields would have previous exposure to metribuzin but would have been sprayed with triazine herbicides, which have a similar mode of action. In view of the experience of New Zealand maize growers in the 1980s where repeated applications of the herbicide EPTC over a 5-year period led to its enhanced degradation and failure to control weeds (Lee et al. 1984), similar phenomena cannot be ruled out with other pre-emergence herbicides in high organic matter soils. Although EPTC was effective in controlling both grass and broadleaf weeds there were other options available to replace this herbicide. Currently in New Zealand most of the maize crop is treated 
TABLE 2: Number of grass seedlings that emerged in each soil type after the 6-week seeding of the pots sprayed with one of seven herbicide treatments.

\begin{tabular}{|c|c|c|c|c|c|c|c|}
\hline \multirow[b]{3}{*}{ Treatment } & \multicolumn{7}{|c|}{ Soil type ${ }^{1}$} \\
\hline & \multicolumn{2}{|c|}{ Otorohanga } & \multicolumn{2}{|c|}{ Kaiti } & \multicolumn{2}{|c|}{ Ohinepanea } & \multirow{2}{*}{$\frac{\text { Kaipaki }}{\text { Long }}$} \\
\hline & Short & Long & Short & Long & Short & Long & \\
\hline & \multicolumn{7}{|c|}{ Summer grass (seedlings/pot) ${ }^{2}$} \\
\hline Acetochlor (Roustabout) & 1.5 & 3.9 & 2.0 & 3.9 & 3.6 & 4.9 & 0.3 \\
\hline Acetochlor (Sylon) & 1.4 & 3.7 & 3.5 & 4.1 & 5.8 & 7.1 & 1.5 \\
\hline Alachlor & 2.4 & 4.3 & 2.7 & 3.6 & 7.5 & 8.5 & 1.8 \\
\hline Metolachlor & 0.2 & 1.0 & 0.1 & 0.0 & 2.8 & 2.4 & 0.5 \\
\hline Dimethenamid & 0.6 & 5.1 & 1.5 & 3.3 & 4.8 & 8.5 & 3.5 \\
\hline Acetochlor+atrazine & 1.4 & 5.2 & 1.7 & 2.8 & 5.4 & 9.3 & 4.8 \\
\hline Acetochlor+metribuzin & 0.4 & 3.8 & 1.5 & 2.1 & 3.4 & 7.0 & 6.3 \\
\hline \multirow[t]{2}{*}{$\operatorname{LSD}(\mathrm{P}=0.05)$} & \multicolumn{7}{|c|}{1.26 applies to both rows and columns } \\
\hline & \multicolumn{7}{|c|}{ Rough bristle grass (seedlings/pot) ${ }^{2}$} \\
\hline Acetochlor (Roustabout) & 3.8 & 4.1 & 1.5 & 2.3 & 3.5 & 2.5 & 2.4 \\
\hline Acetochlor (Sylon) & 4.4 & 4.6 & 0.3 & 2.9 & 3.4 & 2.1 & 2.6 \\
\hline Alachlor & 3.8 & 4.5 & 1.3 & 3.3 & 2.4 & 4.4 & 4.3 \\
\hline Metolachlor & 1.7 & 3.8 & 0.8 & 0.8 & 0.9 & 1.1 & 3.0 \\
\hline Dimethenamid & 4.1 & 5.9 & 2.3 & 3.8 & 3.2 & 2.3 & 3.5 \\
\hline Acetochlor+atrazine & 3.6 & 2.5 & 1.3 & 2.7 & 2.8 & 4.4 & 5.5 \\
\hline Acetochlor+metribuzin & 1.2 & 4.9 & 2.0 & 3.3 & 1.8 & 1.9 & 2.0 \\
\hline \multirow[t]{2}{*}{$\operatorname{LSD}(\mathrm{P}=0.05)$} & \multicolumn{7}{|c|}{1.17 applies to both rows and columns } \\
\hline & \multicolumn{7}{|c|}{ Broom corn millet (seedlings/pot) ${ }^{2}$} \\
\hline Acetochlor (Roustabout) & 3.2 & 3.1 & 3.5 & 4.2 & 4.1 & 1.9 & 1.1 \\
\hline Acetochlor (Sylon) & 2.9 & 4.7 & 2.8 & 3.4 & 2.9 & 2.4 & 1.3 \\
\hline Alachlor & 2.9 & 3.4 & 3.0 & 4.2 & 3.6 & 2.8 & 1.0 \\
\hline Metolachlor & 2.9 & 2.3 & 3.3 & 2.5 & 3.6 & 4.0 & 2.6 \\
\hline Dimethenamid & 3.9 & 4.6 & 3.5 & 4.6 & 3.6 & 1.6 & 2.3 \\
\hline Acetochlor+atrazine & 3.0 & 3.7 & 1.5 & 2.7 & 3.5 & 4.9 & 4.5 \\
\hline Acetochlor+metribuzin & 1.6 & 4.0 & 3.3 & 2.4 & 1.7 & 3.1 & 1.5 \\
\hline $\operatorname{LSD}(\mathrm{P}=0.05)$ & \multicolumn{7}{|c|}{0.99 applies to both rows and columns } \\
\hline
\end{tabular}

\footnotetext{
${ }^{1}$ Soil types: Short $=$ short term and Long $=$ long term maize growing.

${ }^{2}$ Average seedling numbers in untreated were: summer grass 9.4 , rough bristle grass 10.0 and broom corn millet 10.0 seedlings/pot.
} 
with either acetochlor alone or in combination with atrazine and if either or both of these herbicides were to prove ineffective due to enhanced degradation, there are few options available for effective control of many weeds. Enhanced degradation has already been reported from laboratory studies with both nicosulfuron and atrazine in a Horotiu silt loam soil from the Waikato (James et al. 1999; James 2008). An evaluation of enhanced degradation in seven soils with a long history of maize production is currently being tested through detailed laboratory and field investigations.

\section{CONCLUSION}

In the soils evaluated in this study, metolachlor was more effective than all other herbicides tested in controlling summer grass and rough bristle grass, but all herbicides were less effective in controlling the large seeded broom corn millet than the other two grasses. All the herbicides except metolachlor were generally less effective in the soils with a long history of maize growing.

\section{ACKNOWLEDGMENTS}

Thanks to Nick Pett and Sarah Keatley, B.Sc.Tech. students from Waikato University, who spent their holidays planting thousands of seeds, and to the Foundation for Arable Research who funded this project.

\section{REFERENCES}

James TK 2008. Characterisation of herbicide behaviour in some innovative growing media. PhD Thesis, Massey University, Palmerston North, New Zealand. 227 p.

James TK, Rahman A, Holland PT 1999. Degradation and persistence studies with the sulfonylurea herbicide nicosulfuron. Workshop on Environmental Aspects of Pesticide Use. Hamilton, New Zealand. p. 20 (Abstract only).

James TK, Rahman A, Mellsop J 2000. Weed competition in maize crop under different timings for post-emergence weed control. New Zealand Plant Protection 53: 269272

James TK, Rahman A, Trolove M 2006. Optimal timing for post emergence applications of nicosulfuron for weed control in maize. New Zealand Plant Protection 59: 250254.

James TK, Rahman A, Trolove M 2007. Optimising time of planting and herbicide application for control of problem weeds in maize. New Zealand Plant Protection 60: 183-188.

Krutz LJ, Burke IC, Reddy KN, Zablotowicz RM 2008. Evidence for cross-adaptation between s-triazine herbicides resulting in reduced efficacy under field conditions. Pest Management Science 64: 1024-1030.

Krutz LJ, Zablotowicz RM, Reddy KN, Koger CH, Weaver MA 2007. Enhanced degradation of atrazine under field conditions correlates with loss of weed control in the glasshouse. Pest Management Science 63: 23-31.

Lee A, Rahman A, Holland PT 1984. Decomposition of the herbicide EPTC in soils with a history of previous EPTC applications. New Zealand Journal of Agricultural Research 27: 201-206.

Rahman A 1985. Weed control in maize in New Zealand. In: Eagles HA, Wratt GS ed. Maize - Management to Market. Agronomy Society of New Zealand Special Publication No. 4, Palmerston North, New Zealand. Pp. 37-45.

Rahman A, Burney B, Whitham JM, Manson BE 1976. A comparison of the activity of herbicides in peat and mineral soils. New Zealand Journal of Experimental Agriculture 4: 79-84.

Rahman A, James TK 1983. Decreased activity of EPTC + R-25788 following repeated use in some New Zealand soils. Weed Science 31: 783-789.

Rahman A, James TK 1994. Field persistence of some maize herbicides in two soils. Proceedings of the 47th New Zealand Plant Protection Conference: 6-10. 
Rahman A, James TK 2002. Minimising environmental contamination by selecting appropriate herbicide dose. In: Kookana RS, Sadler R, Sethunathan N, Naidu R ed. Environmental Protection and Risk Assessment of Organic Contaminants. Science Publishers Inc., NH, USA. [ISBN 1-57808-193-9]. Pp. 209-224.

Reid JB, Stone PJ, Pearson AJ, Cloughley C, Wilson DR 1999. 'The Maize Calculator' - a simple system for predicting fertiliser nitrogen requirements of maize. Agronomy New Zealand 29: 73-74. 